\title{
Levitikus as agtergrond van Markus 5:25-34, geïnterpreteer in terme van eer-en-skaamte
}

\begin{abstract}
Author:
Elritia le Roux ${ }^{1}$

Affiliation:

${ }^{1}$ Department of New

Testament Studies,

University of Pretoria,

South Africa

Note:

Elritia le Roux participates

as research associate

of Prof. Dr Ernest van

Eck, Department of New

Testament Studies, Faculty

of Theology, University of

Pretoria, South Africa
\end{abstract}

\section{Correspondence to:}

Elritia le Roux

email:

propeleroux@googlemail. com

Postal address:

PO Box 149, Kriel 2271

South Africa

Dates:

Received: 20 July 2010

Accepted: 02 Feb. 2011

Published: 13 Apr. 2011

How to cite this article:

Le Roux, E., 2011 'Levitikus

as agtergrond van Markus

5:25-34, geïnterpreteer in

terme van eer-en-skaamte',

HTS Teologiese Studies/

Theological Studies 67(3),

Art. \#911, 8 pages. DOI:

10.4102/hts.v67i3.911

(C) 2011. The Authors

Licensee: OpenJournals

Publishing. This work

is licensed under the

Creative Commons

Attribution License.
Leviticus as background to Mark 5:25-34 interpreted in terms of honour and shame

This article investigated whether Mark 5:25-34 proposes a radical discontinuity with the Jewish purity codes and subsequently, holds drastic liberating implications for women as far as access to the temple is concerned and more existentially speaking, access to Yahweh. It determined whether Leviticus speaks about women in such an androcentric and exclusive manner and whether Jewish culture is indeed so discriminating. This article argued that Mark 5:25-34 does indeed radically turn the Jewish purity codes upside down and that the Jesus movement proclaims a drastic liberation for women from social marginalisation. However, the original meaning of the text in Leviticus should not be viewed so negatively. The dreadful consequences of the exile and the destruction of the temple lead to the idea amongst the orthodox rabbi's that the purity codes should be maintained in a very strict way. These codes were thought to ensure that the holiness of Yahweh would manifest in the social sphere, the people of Yahweh would be blessed and a catastrophe of these immense proportions would be avoided in future. Unfortunately, this lead to the degeneration of the cult, that became exclusive as many people were deprived from the presence of Yahweh. The author of the Gospel according to Mark is reacting to this and clearly voices his criticism against this marginalisation.

\section{Inleiding en agtergrond}

Dit wil voorkom of Markus se narratief van die vrou wat aan bloedvloeiing gely het in direkte kontras is met die beeld van die vrou wat deur die androsentriese skrywers van Levitikus geskep word. In teenstelling met hierdie beeld, is die vrou in die Markus-narratief aktief; sy is die een wat aanraak, wat ken, wat weet en ontdek en optree. Hoewel haar toestand vir haar bepaalde beperkinge inhou, word sy daarvan bevry en styg sy uit bo die sosiale afgesonderdheid wat die Levitikusteks dikteer. Terwyl Jesus in die Markus-narratief met die vrou gesels, word die aandag gevestig op haar innerlike sterkte; haar geloof. Hieruit blyk dat die Evangelie van Markus met hierdie narratief die implikasies van die Jesus-beweging vir vroue illustreer, naamlik fisiese en sosiale bevryding.

\section{Algemene vertrekpunt}

Die konsep van reinheid en onreinheid is aan kulturele antropoloë en Bybelwetenskaplikes bekendgestel deur Mary Douglas in haar boek Purity and danger: An analysis of the concepts of pollution and taboo (1966, vgl. Van Eck 1995:196). Douglas gaan van die voorveronderstelling af uit dat gemeenskappe hulle onderskeidelike wêrelde in terme van reinheid en onreinheid definieer. 'n Studie van reinheid is daarom 'n studie van simboliese sisteme (Douglas 1966:34). Wanneer iets uit plek is en die kategorie waartoe dit onder normale omstandighede behoort daardeur geskend word, word dit as vuil of onrein beskou. 'n Voorbeeld hiervan is mis waar koeie gemelk word. Dit is nie onrein nie, want dit is normaal dat daar mis sal wees daar waar koeie beweeg; dit is dus in plek. Wanneer hierdie mis egter deur die stewels van die boer in sy huis ingedra word, kom die mis voor in die huis, 'n plek voor waar dit nie hoort nie en dan is dit onrein. Onreinheid verwys dus na die verkeerde ding op die verkeerde tyd en plek. Wanneer dit so verstaan word, vorm reinheid 'n abstrakte term wat die ordening van 'n sosiale sisteem kenmerk (Neyrey 1991:274).

Volgens Douglas (1966:37-39) word lyne in die antieke wêreld rondom dinge, plekke, aktiwiteite en tye getrek. Hierdie lyne dikteer 'wie, wat, wanneer en waar' mag doen en vorm 'n strukturele reëling wat die abstrakte waardes van 'n samelewing kommunikeer (vgl. Malina 1981:25-27). Douglas (1966:38-39) voer verder aan dat hierdie reëling die ervaring van individue bemiddel. Biale (1984:148) stel ook die reinheidswette voor as 'n pilaar waarop die rituele praktyke van die tempel berus het. Reinheid in hierdie konteks het beteken dat persone in 'n toestand verkeer waar hulle tot die tempel en gevolglik die teenwoordigheid van die goddelike toegelaat word. Onreinheid is ' $n$ toestand wat ' $n$ persoon toegang tot enige iets wat met die teenwoordigheid 
van God geassosieer word verbied. Biale (1984:154) wys ook daarop dat onreinheid as sodanig nie 'n sonde was nie, maar dat dit wel ' $n$ sonde was om in ' $n$ toestand van onreinheid (onheiligheid) na die tempel toe te kom. God kan, volgens hulle beskouing, nie onreinheid voor sy aangesig verdra nie. Levitikus 19:2 is ' $n$ goeie voorbeeld van die begronding van

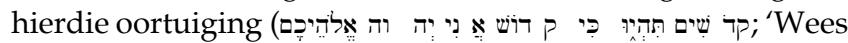
heilig, want Ek die Here julle God is heilig').

God word geken deur die wyse waarop Hy ordelik geskep het en dinge gekompartementiseer en van mekaar gekei het. Dit is ook hoe God die skepping seën. Wanneer die seën van God onttrek word, is daar wanorde en chaos. Daarom beteken om heilig te wees om by die onderskeibare kategorieë van die skepping te hou en dit behels die korrekte diskriminasie en definisie (Douglas 1966:51).

Volgens Neusner (1979:103-127) het hierdie verstaan van heiligheid in die besonder in die sentrale simbool van Israel se ethos neerslag gevind, naamlik die tempel en die tempelkultus. Daarom was die tempel, volgens Van Eck (1995:199), die primêre nabootsing van die idee van orde en reinheid wat in die skepping tot stand gebring is en daarom ook die dominante simbool van Israel se kultuur, godsdiens en politiek ${ }^{1}$.

Heiligheid beteken in die eerste instansie 'heelheid', en daarom is alle mense met die een of ander liggaamlike gebrek as onheilig en gevolglik onrein beskou (bv. mense wat verlam, kreupel en blind is). Volgens die Tora is hierdie mense toegang tot die tempel en gevolglik ook die teenwoordigheid van Jahwe geweier.

Douglas (1966:115) neem hierdie teorie nog 'n stappie verder en volgens haar word die menslike liggaam uiteindelik die replika van die sosiale sisteem. Dit beteken dat in 'n kultuur wat deur sterk reinheidsmaatreëls gekenmerk word, soos die Joodse kultuur, daar 'n groot sensitiwiteit heers ten opsigte van die liggaam. Die vel vorm die grens van die liggaam, maar het ook openinge wat toegang tot die liggaam verleen soos die poorte van 'n stad. Hierdie openinge moet dus met die grootste sorg bewaak word (bv. die oë, ore, mond en genitalië). Omdat die grens van die liggaam oorskry word, is die vloei van liggaamsvloeistof uit enige van hierdie openinge as onrein beskou. Dit beteken dat iemand wat spoeg of ' $n$ vrou tydens haar maandstonde dus onrein is. Juis om hierdie rede is menstruale bloedvloeiing en die vloei van semen met die grootste omsigtigheid deur die reinheidsreëls hanteer.

\section{Metodologie}

Hierdie artikel het 'n sosiaal-wetenskaplike kritiese en literêrkritiese $^{2}$ benadering kombineer ten einde'n meer omvattende

1.Politiek in die antieke Mediterreense konteks het verband gehou met kollektiewe handeling, was deur magstrukture bymekaar gehou en het die vertikale organisasiestruktuur van die samelewing gevorm (kyk Van Eck 1995:206).

2. Hayes en Holladay (1982:68) oordeel dat die literê-kritiese benadering die waarde van 'n teks as literatuur kan vasstel deurdat die outeur, die histories-kulturele en ander aspekte wat moontlik' $n$ invloed op die teks kan hê vir eers opsygeskuif word en daar slegs op 'n immanente lees van die teks gefokus word (kyk ook De Villiers 2006:824). lees van Markus 5:25-34 daar te stel. Die besondere fokus was Levitikus 15:24-29 en die effek daarvan op Markus 5:25-34. Elliot (1991:3) toon aan dat 'n kombinasie van die literêre en die sosiaal-wetenskaplike metode noodsaaklik is ten einde tekste binne konteks te kan verklaar, in terme van die oorspronklike kommunikasie tussen die outeur en die bedoelde gehoor. Die doel van die sosiaal-wetenskaplike lees van tekste is ook om die retoriese effek van die teks binne die oorspronklike sosiale konteks daarvan vas te stel. Elliot (1989:6) is van mening dat die genre, struktuur, inhoud, temas en boodskap van ' $n$ bepaalde teks deur die sosiale en kulturele kragte, wat in 'n spesifieke sosiale struktuur binne 'n bepaalde historiese konteks geld, gevorm word en dat dit ' $n$ bepaalde respons konstitueer. Hierdie artikel sluit by sy benadering aan. So word die bedoeling van die teks binne die konteks vasgestel (vgl Van Aarde 2007:65). Elliott (1989:5-6) toon aan dat die sosiaal-wetenskaplike lees van tekste twee fokuspunte het. Die eerste maak gebruik van die sosiale wetenskap om teorieë en modelle te vorm en die data te analiseer wat lig werp op die antieke Mediterreense wêreld en die vroeë Christelike gemeenskap en wêreld. Die tweede fokuspunt is daarop gerig om lig te werp op die retoriese strategie wat deur die outeur met die teks beoog is binne die sosiale konteks waarin dit ontstaan het. 'n Sosiaal-wetenskaplike lees van tekste ondersoek dus ook die narratiewe wêreld van die teks, die kommentaar wat die outeur lewer op die sosiale konteks.

'n Gekombineerde literêre en sosiaal-wetenskaplike lees, hoewel onderskeibaar, is weliswaar onskeibaar en albei noodsaaklik vir die omvattende verstaan van 'n teks. Tog behoort die literêre analise die sosiaal-wetenskaplike lees van die teks vooraf te gaan. Die rede hiervoor is dat die sosiale en die historiese konteks nie direk vir ons toeganklik is nie, maar hoogstens deur navorsers gekonstrueer kan word. Vir hierdie konstruksie is 'n literêre analise noodsaaklik (Van Staden 1991:33). Dit gaan hier om die vasstelling van die outeur se strategie (die teks) binne 'n bepaalde situasie (die betrokke situasie.)

Van Aarde (2007:52) stel ook voor dat 'n sosiaalwetenskaplike lees van 'n teks die eksegeet help om te waak teen die eksegetiese fout van etnosentrisme; om die Bybelse teks direk op die omstandighede van die moderne leser van toepassing te maak. Verder oorkom dit die eksegetiese fout van anakronisme, wat dinge wat kronologies eers later in die geskiedenis sosiale verskynsels geword het as sosiale verskynsels in tekste veronderstel in ' $n$ tyd toe dit nog nie bestaan het nie. Eksegete behoort in ag te neem dat die Bybel meer as 2000 jaar gelede ontstaan het, in 'n primêr ongeletterde gemeenskap, waarvan $90 \%$ kleinboere was, terwyl die hedendaagse realiteit dié van 'n geïndustrialiseerde, postmoderne 'wêrelddorp', waarin mense vrylik toegang tot inligting het, is (Van Aarde 2007:65).

\section{Navorsingsvraag}

Die vraag waarop in hierdie artikel gefokus word, is of Markus 5:25-34 wel 'n radikale breuk met die Levitiese 
reinheidsmaatreëls veronderstel en gevolglik ingrypende bevrydende implikasies vir vroue inhou, in die besonder wat toegang tot die tempel en meer eksistensieel, tot die teenwoordigheid van Jahwe, betref. Deel van hierdie vraag is of Levitikus wel androsentries en uitsluitend oor vroue praat en of die Joodse kultuur in hierdie verband werklik so diskriminerend was. Verder word daar ook gefokus op die vraag of die eer-skande model van Bruce Malina voorsiening maak vir sosiale interaksie waar die vrou die eer van 'n Joodse man in die openbaar uitdaag.

\section{Hipotese}

Die hipotese van hierdie artikel is dat Markus 5:25-34 die Joodse reinheidsreëls radikaal op sy kop keer en dat die Jesus-beweging inderdaad 'n ingrypende bevryding van sosiale marginalisasie vir vroue verteenwoordig. Die artikel toon verder aan dat die aanvanklike bedoeling van die teks in Levitikus nie so negatief was ten opsigte van die marginalisasie van vroue nie, maar dat die uitkoms van die ballingskap en die verwoesting van die tempel 'n gevoel onder die ortodokse Joodse rabbi's tot gevolg gehad het dat daar streng vasgehou moes word aan die reinheidsreëls. Hierdie reëls sou die heiligheid van Jahwe in die sosiale sfeer laat neerslag vind, sodat die volk geseën sal word en 'n katastrofe van hierdie omvang in die toekoms vermy sal word. Onrein persone is kontak met die tempel en enige ander heilige voorwerpe geweier, maar kon met hulle alledaagse take voortgaan. Later word totale segregasie voorgestel en enige kontak met 'n onrein persoon sou 'n potensiële reinheidsrisiko wees (vgl Biale 1984:166-167). Dit het ongelukkig die gevolg gehad dat die kultus eksklusief geword het en dat die teenwoordigheid van Jahwe van vele mense ontneem is. Hierdie artikel argumenteer dat die outeur van die Markus-evangelie, in navolging van die Jesus-saak, baie sterk hierop reageer en sy kritiek inderdaad teen hierdie marginalisasie uitspreek. Verder word daar by Crook (2008:23-24) aangesluit dat die eer-skande-model van Bruce Malina, hoewel van onskatbare waarde vir 'n sosiaalwetenskaplike lees van die teks, tog in hierdie geval verfyn moet word om die optrede van die vrou in Markus 5 te akkommodeer. Die model was immers nie bedoel om sosiale optrede te voorspel nie, maar om dit te verduidelik.

\section{'n Sosiaal-wetenskaplike lees van Markus 5:25-39: 'n Kritiese reaksie op androsentrisme in Levitikus} 15:24-29

Marcus (1999:366) onderstreep die sosiale, ekonomiese en godsdienstige implikasies van die vrou in Markus 5 se situasie. Sy is naamloos en onrein en as gevolg daarvan uitgesluit van die godsdienstige gemeenskap. Daarom leef sy in isolasie en armoede vanweë haar langdurige mediese koste.

In Markus 5:25-39 wyk Markus van sy gebruiklike parataktiese styl af en skets by die leser of hoorder 'n simpatieke prentiie van die vrou se situasie nog voor die narratief begin (France 2002:236). Die opeenhoping van partisipia in die openingsin beklemtoon die meedoënlose vermenigvuldiging van die vrou se nood oor 'n tydperk van 12 jaar (Marshall 1989:104). Die lesers of hoorders word gunstig teenoor haar gestem, ten spyte van die verwerplike aard van haar klagte, veral in die lig van die Joodse reinheidsmaatreëls. Volgens Myers (1990:201202) verskuif Jesus sy primêre verantwoordelikheid teenoor die dogtertjie van Jaïrus, wat aan die bopunt van die eerskaal is, na hierdie statuslose vrou wat haarself heel onder aan die statusleer bevind, deur eers aan haar aandag te skenk. Hierdie radikale omkering van waardigheid was bedoel om te skok en gevolglik, te bevry.

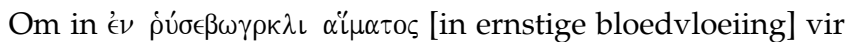
12 jaar te wees, is sekerlik 'n soort menstruale afwyking, selfs al kan die presiese aard van die toestand nie vasgestel word nie. Dit is egter nie hier van belang nie. Menstruale onreinheid is ' $n$ prominente besorgdheid in die $\mathrm{Ou}$ Testament (Lev 15:19-33) en het later die onderwerp van 'n hele traktaat in die Mishnah geword, naamlik die Niddah. Daarin word eksplisiet aangetoon dat enige kontak met 'n vrou gedurende maandstonde, selfs normale maandstonde, ten sterkte vermy moet word. Die vrou se jarelange en vrugtelose soeke na genesing was dus nie net deur haar fisiese ongemak gemotiveer nie, maar veral deur haar sosiale en kultiese isolasie.

Haar bygelowige gedrag word veroorsaak deur haar toestand (waarskynlik kroniese vaginale bloeding), wat haar tot ewigdurende onreinheid verdoem en haar'n element van chaos maak vir enige iemand wat met haar in kontak sou kom. Dit verhoed haar ook om in die openbaar te verskyn. Die vrou se opvatting dat deur slegs aan Jesus se kleed te raak genesing sal bewerkstellig, veronderstel 'n primitiewe, selfs magiese verstaan van genesing. Daarom neem sy aksie en is sy die een wat aanraak. Hierdie aksie word grammaties uitgelig deur die woord $\eta \psi \alpha \tau$ [aanraak], die eerste indikatiewe vorm na 'n reeks partisipia. Dit onderstreep die intensiteit en vorm 'n dramatiese klimaks. Onmiddellik na hierdie aanraking is die vrou genees. Die verteller van die Evangelie gaan egter vernuftig te werk om hierdie primitiewe oortuiging die nek in te slaan deur aan te toon dat die basis van haar genesing

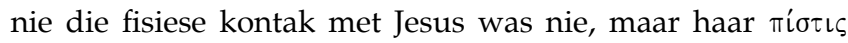

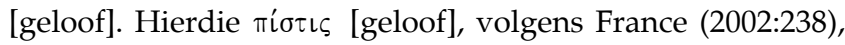
veronderstel eerder ' $n$ praktiese oortuiging van Jesus se mag en/of gesag as 'n ontwikkelde teologiese verstaan van wie Hy is.

Hierdie genesing behels die aanraking van ' $n$ vrou wat ritueel onrein is en daarmee die oorkoming van die beperking van die Levitiese reinheidsmaatreëls. Die Ou-Testamentiese

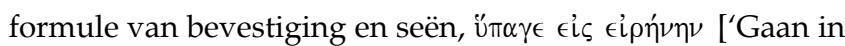
vrede'] (vgl Rig 18:6; 1 Sam 1:17; 2 Sam 15:9) stel dat sy nou

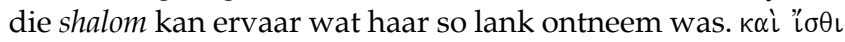
ì dui daarop dat haar genesing 'n langdurige resultaat gehad het; dat die effek van die heling was dat sy rein verklaar is en haar regmatige plek in die gemeenskap kon inneem. 
Van Bruggen (1988:126) beklemtoon dat Jesus die vrou

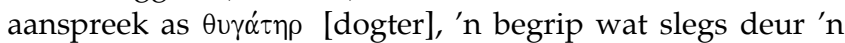
Joodse leraar gebruik is wanneer hy na ' $n$ vrou verwys het as deel van die gemeenskap van die heiliges, die 'dogters van Israel'. Van Bruggen oordeel dus dat Jesus, wanneer hy die vrou as 'dogter' aanspreek en haar in geloof genees, haar in vrede aanneem as 'n kind van God. Jesus gee hierdie vrou terug aan die gemeenskap en aan die gesin van Israel en rig haar op ten aanskoue van die hele skare (kyk Mark 3:31-34, te wete Jesus se herdefiniëring van die familie).

\section{Die aanvanklike betekenis van Levitikus 15:24-29 en die verwording daarvan in die na-ballingskap periode}

Dit is maklik vir die moderne leser, met moderne denkwyses en waardes, om die priesterlike wantroue in die seksuele verkeerd te verstaan (Gerstenberger 1996:197). Bybelse tekse, wat handel oor die liggaamlike en die seksuele, verkondig definitief nie ' $n$ vyandigheid ten opsigte van die liggaam of ' $n$ moralistiese preutsheid nie; daarvoor is die $\mathrm{Ou}$ Testament veels te oop vir die genot van die lewe en die vreugde van die erotiese (vgl Hooglied). Dit laat egter die vraag ontstaan waarom Levitikus 15 so streng oor hierdie aangeleenthede handel. Oor die algemeen het die antieke mens die sfeer van die seksuele met die nodige hoop en vrees bejeën, omdat daar geglo is dat daar in die seksuele 'n goddelike energie aanwesig is wat kreatief tot uiting kom in verlange, begeerte, liefde, swangerskap en geboorte. In die seksuele gaan dit dan primêr om herskepping, wat weer eens die sosiale spieël van die hemelse sfeer beteken, omdat dit gaan oor die skep van lewe soos wat God geskep het. Die fatale gevolge van seksualiteit vir 'n moeder wat tydens geboorte sterf, of die destruktiewe krag van seksualiteit in owerspel, bevestig die krag van seksualiteit as'n mag. Daarom moet seksualiteit met die nodige versigtigheid en wysheid hanteer word. Seksualiteit het in die antieke wêreld beide die elemente van die fassinerende en die onheilspellend bevat, die goddelike en die menslike, en daarom was dit 'n uiters belangrike sfeer van die menslike lewe wat die godsdiens ${ }^{3}$ en die vroomheid van die dag betref het (Gerstenberger 1996:197). So ook stel Biale (1984:147) dat daar in die meeste Ou Nabye Oosterse kulture 'n vrees vir bloeding en 'n ongemaklikheid was ten opsigte van die misterie van die menstruale siklus en die verbintenis daarvan met geboorte. Menstruasie is gevolglik dikwels met die dood geassosieer, aangesien 'n gebrek daarvan verbind is met geboorte.

Daarbenewens was die antieke Israeliete baie versigtig wat die mag van seksualiteit betref sover dit om die kultus gegaan het. Om hierdie rede het hulle hulself van seksuele omgang weerhou voor groot offerseremonies.

Die reinheidsmaatreëls in Levitikus bepaal dat indien daar 'n vloei vanuit die vlees van die vrou voorkom, hetsy normaal

3.Godsdiens het die betekenissisteem van die samelewing gevorm en voer om daardie rede terug na die sosiale, ekonomiese en politieke sisteem wat die geheel verenig deur ' $n$ implisiete of eksplisiete ideologie (kyk Malina 1993). of abnormaal, sy onrein is vir sewe dae. Sodanige Joodse vroue het die status gehad van niddah, per definisie uitgesluit uit die kultiese tuimte. Al hierdie reinheidswette het, volgens Biale (1984:147), dieselfde bedoeling gehad, naamlik om die onrein persone (of objekte) uit die goddelike woning van die tempel uit te sluit.

Hierdie onreinheid beïnvloed ook haar omgewing. In die eerste plek is die man wat haar sou aanraak onmiddellik ook onrein. Die beddens en die sitplekke waarop sy sit was ook as onrein beskou. Gerstenberger (1996:204) beklemtoon dat hierdie beoordeling van menstruasie vanuit 'n manlike perspektief geskied; Levitikus is besorgd oor die implikasies wat kontak met 'n vrou wat maandstonde het vir 'n man inhou.

Vir die menstruerende vrou om weer toegang tot die kultus te verkry behels die bring van 'n offer en die voorskrif is dat 'n duif geoffer moet word. Die vrou kon egter nie haar offer tot by Jahwe bring nie, maar bloot tot by die priester, by die ingang van die tent van ontmoeting (Gerstenberger 1996:205).

Biale (1984:148) merk in hierdie verband ook op dat hierdie reinheidswette grootliks die seksuele optrede van mense gereguleer het. Dit het tot gevolg gehad dat die periode waarin normale seksuele omgang hervat is met ovulasie saamgeval het wat voortplanting bevorder het.

Gebruike van segregasie en uitsluiting het veral na die verwoesting van die Tweede Tempel in die sfeer van sinagogale aanbidding voorgekom, aangesien die sinagoge 'n simboliese plaasvervanger vir die tempel geword het (Biale 1984:148; kyk ook post-Ou-Testamentiese tekste). Die Halakhah het 'n veel strenger maatreël ten opsigte van die niddah gehandhaaf. Volgens Levitikus was die niddah slegs onrein vir 'n periode van sewe dae, maar volgens Rabbynse wetgewing was sy vir tot veertien dae onrein (Biale 1984:153). Gedurende hierdie periode is die vrou toegang tot die sinagoge geweier en mag sy nie gaan bid of die seënbede opgesê het nie, want dan sou sy die naam van God moes uitspreek. Sy mag ook nie aan die boekrol van die Tora geraak het of selfs daarna kyk wanneer die kantor dit aan die gemeente gewys het nie.

Volgens Milgrom (1991:984) het die Mishnah hierdie reinheidsmaatreëls baie strenger geïnterpreteer. Rabbi Nehemia skryf dat selfs die asem van 'n vrou tydens maandstonde onrein is en Rabbi Jokanan, dat ' $n$ man verbied word om selfs in die voetstappe van 'n vrou wat menstrueer te loop, aangesien dit net so onrein soos 'n lyk is. Die Mishnah gaan ook verder deur die vrou te verbied om te bak, te kook of saam met die mense van haar huishouding te eet. Lede van die huishouding word selfs verbied om haar te groet of om na haar te kyk. Sy mag nie aan die huisgodsdiens deelneem nie en die naam van God mag nie in haar teenwoordigheid genoem word nie. Hierdie streng instruksies is veral in Palestina geïmplementeer, aangesien die land heilig was en die heiligheid van Jahwe in die alledaagse praktyke van die mense neerslag moes vind. Volgens Milgrom (1991:949) het die verwoesting van die tempel vir priesters as 'n verdere 
aansporing gedien in die toepassing van hierdie reëls. Menstruale bloed is as wederkerigheid vir bose magte beskou in alle primitiewe samelewings waar die sosiale sfeer in terme van rein en onrein gedefinieer is. Die vrou wat menstrueer is nie alleen geïsoleer nie, maar is uitgesluit. In

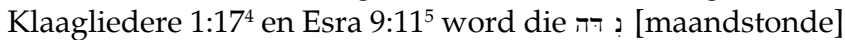
die metafoor vir uiterste besoedeling en afsku. Milgrom (1991:953) oordeel dus dat getuienis uit die na-ballingskap geskrifte van die rabbi's die toegewendheid van die Tora ten opsigte van vroue wat menstrueer verwerp en die houding teenoor hulle grootliks deur vrees gedomineer is.

\section{Die sosiale kritiek van Markus 5:25-34 op die eksklusiwiteit van die Joodse reinheidsreëls}

Seldwidge (1984:619) voer aan dat die rede waarom die narratief van die vrou met bloedvloeiing in die Markus-evangelie behoue gebly het, is omdat dit herinner aan die vroeë Christendom se breuk met die Joodse reinheidsisteem, wat vroue van die kultus en die gemeenskap uitsluit. Reinheidmaatreëls het die beweging van vroue in die kultus, samelewing en die huis beperk. Daarbenewens was al die amptelike kultiese handelinge in die hande van mans. Vroue het geen pligte of verantwoordelikhede binne die Joodse kultus gehad nie. Die enigste rol wat 'n vrou, volgens die skrywers van Levitikus mag speel, is dié van moeder en huishoudster. Die skrywer van die Evangelie van Markus lewer 'n tradisie oor wat in opstand gekom het teen hierdie eksklusiewe praktyke. Dit is in lyn met die Jesus-beweging wat, in navolging van Jesus, per definisie anti-patriargaal, nie-seksisties en 'n oop huishouding was. Die wonderwerkverhaal van die vrou wat van bloedvloeiing genees word laat die reinheidsisteem en die beperkende sosiale kondisionering verkrummel. Jesus berispe nie die vrou omdat sy as iemand wat onrein is Hom aanraak nie. Nee, sy word eerder die sentrale karakter in die verhaal. Die outeur onderstreep haar genesing en haar geloof. Jesus erken haar as sy dogter en sy gaan in vrede.

Myers (1990:201) is ook van die oortuiging dat die primêre betekenis in hierdie narratief in die feit lê dat Jesus die prioriteit van die hoogs onvanpaste lastigheid van die vrou aanvaar bo die 'korrekte' sosiale konvensie. So bevestig die verhaal dat die Jesus-beweging vroue van fisiese en sosiale lyding bevry.

\section{'n Herdefiniëring van die sosiaal- wetenskaplike model wat voorsiening maak vir die uitdaging van eer deur vroue}

Eer en skaamte bly die deurslaggewende en beslissende kulturele waarde in die antieke Mediterreense samelewing.

4.'Sion steek haar hande uit om hulp, maar daar is niemand wat haar bystaan nie. Die Here het vir Jakob aan alle kante vyande ontbied. Jerusalem het onder hulle soos 'n onrein vrou geword.'

5.'Die land wat julle in besit gaan neem, is ' $n$ onrein land. Die heidennasies het dit onrein gemaak. Hulle het dit van kant tot kant besmet met hulle afskuwelike, onrein optrede.
Die eer-en-skaamte-model is die resultaat van kultuurantropologiese navorsing wat voortgevloei het uit die waarneming van menslike interaksie, soos verstaan vanuit antieke tekste (Crook 2008:1). Die eer-skande-model is van toepassing waar daar outoriteit, geslagsrolle en respek ter sake is. Outoriteit is ' $n$ simboliese realiteit en anders as fisiese realiteit is dit die vermoë om ander te beheer sonder fisiese krag. Geslagsrolle verwys na die verskillende standaarde van aanvaarbare gedrag vir mans en vroue onderskeidelik. Respek het te make met die houding wat'n mens behoort te hê jeens diegene wat jou bestaan reguleer en sluit magshebbers en gode in (Crook 2008:2).

Malina (1981) toon in sy model aan dat daar twee soorte eer bestaan, te wete 'toegeskrewe eer' en 'verworwe eer'. Eersgenoemde verwys na die eer wat aan'n persoon toegeken word op grond van byvoorbeeld geboorte, etnisiteit, familie en geslag. Laasgenoemde kan vermeerder of verminder word deur uitdaging en respons wat op ' $n$ daaglikse basis binne die agonistiese konteks van die 1e eeuse Mediterreense samelewing. Eer is verstaan deur die mense van die antieke Mediterreense samelewing as iets wat slegs in beperkte hoeveelheid bestaan. Binne die eer-skande-model van Malina geld die volgende: Enige interaksie tussen twee mense wat nie familie van mekaar is nie, is as 'n uitdaging van eer beskou. Vier dinge moet in enige uitdaging van eer geskied:

- iemand moet iets aan iemand anders doen of vir iemand anders sê

- wat gedoen of gesê is, moet geïnterpreteer word as synde 'n uitdaging van eer

- 'n reaksie moet gebied word

- die reaksie moet geëvalueer word deur die openbare hof ${ }^{6}$.

As gevolg van hierdie laaste stap moet uitdagings en response ten opsigte van eer in die openbaar geskied. Uitdaging en reaksie kan verder alleenlik tussen twee persone van gelyke sosiale status plaasvind. So kan 'n kleinboer byvoorbeeld nie die eer van 'n koninklike uitdaag nie.

Eer is in die eerste instansie die evaluering van 'n persoon se status in sy of haar eie oë, maar belangriker nog die evaluering van 'n persoon in die oë van die sosiale groepering waartoe hy behoort. Binne Malina se model is daar sekere gedrag wat van mans en vroue onderskeidelik verwag word. 'n Vrou, aldus Malina, het geen eer nie; haar eer is gesetel in haar seksuele reinheid en eksklusiwiteit en haar moederskap. So beskou, beliggaam ' $n$ vrou eerder skaamte as eer, waar skaamte in hierdie sin verstaan word as sensitiwiteit ten opsigte van die eer van die man by wie se eer sy ingebed is, hetsy haar vader of haar eggenoot (Malina 1993:32). Manlike eer het te make met die aggressiewe uitdaging van eer en die soeke na groter eer. Tog is skaamte iets wat alle eervolle mense moet hê, ten einde ' $n$ sensitiwiteit vir verlies aan eer te openbaar. 'n Skaamtelose persoon, in 'n konteks waarin eer en skaamte die belangrikste beslissende waardes is, is absoluut laakbaar. Sulke persone het geen sensitiwiteit ten

6.Binne Crook se model beteken ' $n$ 'openbare hof' dat die vermeerdering of vermindering van eer in die openbaar geskied en wel ten aanskoue van die publiek daar teenwoordig. 
opsigte van hulle eie eer, die eer van die ander lede van hulle groep of die eer van diegene wat 'n hoër sosiale status as hulle het nie (Crook 2008:4).

Die eer-en-skaamte-model van Malina bepaal egter nie watter gedrag as eervol of beskamend beskou word nie. Die evaluering van gedrag as synde eervol of beskamend hang ten nouste af van die uitspraak van die openbare hof.

As kritiek op hierdie model van Malina, stel Wikan dat atropoloë nie daarin geslaag het om kontekste uit verskillende sektore van die samelewing in ag te neem waar vroue wel eer verwerf het nie. Hierdie kontekste toon aan dat eer nie 'n uitsluitlike manlike voorreg was nie, veral nie wanneer in ag geneem word dat $50 \%$ van die samelewing uit vroue bestaan het nie (Wikan 1984:635-652).

Herzfeld (1987:340) is verder van mening dat modelle nie daar is om menslike gedrag te voorspel nie. Wanneer 'n model korrek gebruik word, is dit nie positivisties nie; mense reageer immers nie altyd dieselfde op 'n eksterne stimulus nie. Modelle het eerder ten doel om menslike gedrag te verduidelik. Verder maak Downing (1999:53-73) ook beswaar teen die gelykstelling van vroue aan skaamte en hulle passiewe beperktheid tot die private sfeer van die huis.

Crook (2008:10) se kritiek op Malina se model is primêr gesetel in die antieke Mediterreense diadiese persoonlikheid. Die 1e eeuse Mediterreense persoon het glad nie ons hedendaagse konsep van individu verstaan nie (Malina 1993:66). In stede van individualisme vind ons in die 1e eeuse Mediterreense wêreld ' $n$ baie sterk groepsoriëntasie. Persone is altyd by een of ander groep ingebed. Teenoor die individualistiese oriëntasie is daar hier sprake van ' $n$ diadiese oriëntasie, afgelei van die Griekse woord wat 'paar' beteken. Die diadiese persoonlikheid, teenoor die individualistiese persoonlikheid, is altyd by 'n groep ingebed. Hierdie persoonlikheid het altyd ander in die groep nodig om te weet wie hy of sy regtig is. Hierdie persone internaliseer wat ander sê, doen en dink en vind dit noodsaaklik om die verwagtinge van ander uit te leef. Dit is ook vir hulleself nodig om hierdie interafhanklikheid te toets en hulleself volgens die verwagtinge van ander te evalueer (Malina 1981:67).

Die beeld wat hulle egter van hulleself het moet ooreenstem met die beeld wat die groep van hulle het. Vir die diadiese persoon bly interpersoonlike kontak altyd onpersoonlik, omdat die diadiese persoonlikheid altyd deel vorm van die groter groep en ook met hierdie persoon waarmee hy of sy in kontak is bepaalde gemeenskaplikhede deel. Die ander word dus verstaan as ook ' $n$ lid van die groep (Malina 1981:68).

Aangesien na die self en na die ander verwys word in terme van spesifieke groepe, is die karakter van 'n bepaalde groep ook beskou as uniek en onveranderlik. Elke familie, dorp, stad of volk sou voorspelbaar kon wees en al die individue wat tot hierdie groep behoort sou dieselfde eienskappe openbaar. Dit sou binne hierdie kultuur geen sin gemaak het om ' $\mathrm{n}$ individu in terme van unieke eienskappe te beskryf nie. Die diadiese persoon verklaar menslike gedrag aan die hand van 'n sosiologiese beskouing van mense. ' $n$ Mens sou ook van stereotipering ${ }^{7}$ kon praat.

Vanuit hierdie perspektief beskou, is die verantwoordelikheid vir moraliteit ook ' $n$ kollektiewe aangeleentheid, te wete die verantwoordelikheid van die groep waarby die individu ingebed is. Daar is geoordeel dat indien iets binne die sosiale korpus verkeerd is, dit daartoe kan lei dat individue hulleself aan verkeerde optrede kan skuldig maak. In al die morele en etiese voorskrifte wat ons in die Nuwe Testament vind is die individu dan ook nie die primêre oorweging nie, maar die groep. Dit is geskryf vanuit die perspektief van die supraindividu en die objektiewe horison van die sosiale korpus (Malina 1993:71). Beskrywings van menslike gedrag binne die Nuwe Testament fokus dus op die uiterlike, konkrete handeling. Daar word nie introspeksie gedoen nie, maar die gedrag word geëvalueer op grond van die effek daarvan op die groter groep.

Hieruit lei Crook af dat wanneer dit oor eer gaan, dit nie in die eerste instansie oor die individu gaan nie. Daar behoort eerder uit die staanspoor op die kollektiewe openbare hof gefokus te word, omdat die openbare hof die finale beslissings oor verworwe eer of skaamte kon fel (Crook 2008:10).

Markus 5:24-34 is ' $n$ voorbeeld van 'n uitdaging tussen persone van verskillende sosiale stande, waarin 'n vrou sukses behaal. Die vrou in die narratief konfronteer Jesus met 'n versoek om genesing. Dit kan inderdaad as 'n uitdaging van eer beskou word. Daar is sprake van multivalente ongelykhede in hierdie narratief: Jesus is ' $n$ Joodse man en die vrou nie alleenlik 'n vrou nie, maar boonop 'n onrein vrou. Dit bied aan ons dus 'n voorbeeld dat uitdagings van eer tussen persone van ongelyke sosiale statusse wel moontlik was. Die voorkoms van hierdie gebeure is waarskynlik nie hoog nie, maar die feit dat dit wel gebeur noodsaak dat die sosiaal-wetenskaplike model tog daarvoor voorsiening moet maak (vir ander voorbeelde kyk Mark 7:24-30 of Matt 15:2228, waar Jesus deur 'n Kanaänitiese vrou genader word om haar dogter te genees).

Crook (2008:14) toon verskeie ander voorbeelde aan waar Jesus in twisgesprekke tree met die Fariseërs en die Skrifgeleerdes (ongelykes), wat volgens Malina se model, wat uitdagings tussen persone van ongelyke sosiale status uitsluit, nie sou kon plaasvind nie. Tog kan Jesus, nederige timmerman van Galilea die Sadduseërs (die regerende priesterlike party) uitdaag en in die openbaar van hulle eer ontneem.

As kritiek op Crook se model sou aangevoer kon word dat Jesus en die onrein vrou tog dieselfde sosiale status geniet, omdat hulle beide gemarginaliseerdes is wat as kulties onrein beskou word. So beskou, is die narratief in Markus 5 dan nie ' $n$ uitdaging van eer tussen persone van ongelyke sosiale status nie. Hierdie kritiek is wel problematies in die

7.Stereotipes kan beskou word as vaste paradigmas van groepe waarvolgens al die lede van die groep dieselfde eienskappe vertoon (Malina 1993:69). 
lig van die voorbeelde van Jesus se strydgesprekke met die Fariseërs, Skrifgeleerdes en Saduseërs. Die skrywers van die Evangelies bied hierdie strydgesprekke so aan dat die Fariseërs en Skrifgeleerdes die inisiatief neem en Jesus eerste in die gesprek uitdaag. Dit word dus ten minste so uitgebeeld dat die Fariseërs en Skrifgeleerdes Jesus as hulle gelyke beskou en hulle daarom verwerdig om in gesprek met hom te tree.

Vergelyk in hierdie verband byvoorbeeld die narratief in Matteus 9:1-8 en Lukas 5:17-26, waar Jesus die verlamde man genees. Die Skrifgeleerdes beskuldig Hom van Godslastering, maar nie alleen snoer Jesus hulle die mond nie, hy betoon ook medelye aan die man. Die menigte wat teenwoordig is reageer met ontsag vir God en vorm hier die publieke hof wat eer van die Skrifgeleerdes ontneem en aan Jesus toedig.

Hierdie artikel oordeel dat Crook se model eerder hier gekritiseer word. Indien die Fariseërs, Saduseërs en Skrifgeleerdes Jesus se gesag in die openbaar uitdaag, beskou hulle Jesus as hulle eweknie. Indien hierdie standpunt gehandhaaf word, is Crook wel reg deur te oordeel dat die narratief in Markus 5 dan 'n voorbeeld is van ' $n$ uitdaging van eer tussen persone van ongelyke sosiale status. Jesus kan immers nie deur die Skrifgeleerdes as ' $n$ waardige gespreksgenoot beskou word en terselfdertyd as ' $n$ onrein uitgeworpene in dieselfde kategorie as die vrou wat aan bloedvloeiing ly beskou word nie.

Crook het wel reg dat die Evangelies ook illustreer dat uitdagings van eer tussen persone van ongelyke status wel voorgekom het.

Die bedoeling van ' $n$ model is nie om sosiale gedrag te voorspel nie, maar om die eksegeet te help om dit te verklaar. Daarom is Malina se model problematies, omdat sekere sosiale gedrag nie daardeur verklaar kan word nie. Crook (2008:19) verleen voorkeur aan die belangrikheid van die openbare hof. Sodoende verskuif die fokus van geslagstereotipering na die besluit van die openbare hof of hierdie persoon eer verwerf of verloor het. Omdat die openbare hof die beslissing fel, kon vroue dus eer verwerf deur dapper en aggressief op te tree, soos die vrou in Markus 5 , wat daadwerklik optree en aksie neem ten einde haar eie lot te verander (Crook 2008:19).

Daarbenewens is daar genoegsame getuienis uit die GrieksRomeinse wêreld en die vroeg-Christelike kerk dat vroue wel gesagsposisies in religieuse sfere beklee het. Vroue was ook aktief in die handel en vervaardiging en het geld aangewend op maniere wat tot erkenning gelei het in die stede waar hulle gewoon het (Meeks 1983:24). MacMullen (1980:212) toon byvoorbeeld ook aan dat vroue in hierdie hoedanighede wel as 'patrons' en weldoeners opgetree het. Crook (2008:21) is verder van oordeel dat, indien die getuienis van epigrafie en argeologie ernstig geneem word en daar minder gefokus word op die formele, idealistiese en voorskriftelike geskrifte van die mans van die elite, hoe meer kan redelik aangetoon word dat vroue wel openbare lewens gehad het (vgl Kraemer 1986:183-200). Dit is vir seker so dat hierdie feit nie deur almal in die samelewing goedgekeur is nie en hierdie vroue is konstant daaraan herinner dat hulle besig is om sosiale grense te oortree (vgl Meeks 1983:23-24).

Ook in die geval van vroue is dit die openbare hof wat besluit of ' $n$ vrou eer verwerf het. Sommige vroue het wel daarin geslaag om die verwagtinge wat die samelewing van hulle gehad het, te oortref. Dit is egter die openbare hof wat daaroor besluit of 'n vrou wel in 'n gesagsposisie mag staan en of sy toegelaat word om die eer van 'n man in die openbaar uit te daag. Die openbare hof besluit of hierdie aksies daartoe lei dat sy eer verkry of dat sy haarself en haar huis in die skande dompel.

As beskeie wysiging op Malina se model stel Crook (2008:22) voor dat die openbare hof die fokuspunt behoort te wees waar eer en skande ter sake is. Die gevolg is ' $n$ meer genuanseerde model, wat die data in die tekste beter kan verklaar. Verder onderskei Crook (2008:22) in stede van die begrippe 'toegekende eer' en 'verworwe eer', die terme 'toegerekende eer' en 'gedistrubeerde eer'. 'Toegerekende eer' sal dan verwys na die eer wat 'n persoon reeds vanaf sy of haar geboorte in die oë van die samelewing het en 'gedistrubeerde eer' sal verwys na die eer wat op 'n daaglikse basis opnuut deur die openbare hof versprei word, wanneer een persoon ' $n$ ander in die openbaar stomslaan of ' $n$ daad pleeg wat as ' $n$ uitdaging van eer geïnterpreteer word. Deur so te onderskei word ook aangetoon dat die individuele eienskappe van 'n persoon soos geslag en status deur die openbare hof geïgnoreer kan word. Alleenlik die openbare hof besluit wat skandelik of eervol is en hierdie openbare hof is vloeibaar soos wat kontekste verander.

\section{Slotopmerkings}

Crook se voorgestelde model bied moontlike oplossings vir die moontlike tekorte in Malina se model. Bergant (1994:2340) vra byvoorbeeld na hoe die gedrag van die vrou in Hooglied verklaar kan word. Ten spyte van Israel se streng reinheidskodes ten opsigte van seksualiteit, tree sy dikwels as die aggressor op. Sy gaan laat in die aand uit om haar beminde te gaan soek en nêrens word hierdie optrede van die vrou onder sensuur geplaas of bevraagteken nie. Die boek het immers kanonieke status gekry. Bergant kan nie 'n antwoord bied op hierdie diskrepansie waarvoor Malina se model nie voorsiening maak nie. Crook (2008:23) stel voor dat die oplossing vir hierdie probleem daarin lê dat voorkeur verleen behoort te word aan die openbare hof. Die vrou in Hooglied word nie gesensor vir haar optrede nie. Nie omdat haar optrede nie opspraakwekkend was nie, maar eenvoudig omdat dit nie die wil van die openbare hof was nie.

Hierdie artikel wil Crook se standpunt ondersteun dat ons in Markus 5:24-34 wel 'n vrou het wat die eer van 'n man in die openbaar uitdaag en daarom sal die eer-skande model van Malina ten opsigte van die eer en skaamte tog effens verfyn behoort te word. 


\section{Literatuurverwysings}

Bergant, D., 1994, 'My Beloved is Mine and I Am His (Song 2:16): The Song of Songs and Honor and Shame', Semeia 68, 23-40.

Biale, R., 1984, Women and Jewish Law: An Explanation of Women's Issues in Halakhic Sources, Schocken Books, New York.

Crook, Z., 2008, 'Renovating the House that Bruce Built: Remodelling Ascribed and Acquired Honor', paper presented at the Context Group, Carleton University, Ottawa, 06-08th March.

De Villiers, G., 2006, 'Oor Eksegese en Metodes: Die Reëls van die Spel', Old Testament Essays 19(3), 823-830.

Douglas, M.T., 1966, Purity and Danger: An analysis of the concepts of pollution and taboo, Routledge \& Kegan Paul, London. doi: 10.4324/9780203361832

Drowning, F.G., 1999, 'Honour' among Exegetes', Cathololic Biblical Quarterly 61, 53-73.

Elliott, J.H., 1989, 'Social-scientific study of the Bible and the biblical world', unpublished paper presented at the Mdiv-seminar, Faculty of Theology, unpublished paper presented at the
University of Pretoria, Pretoria, 04th April.

Elliott, J.H. 1991, A home for the homeless: A sociological exegesis of 1 Peter, its situation and strategy, 2 nd edn., Fortress Press, Minneapolis.

France, R.T., 2002, The Gospel of Mark: A Commentry on the Greek Text, William Eerdmans Publishing Company, Michigan.

Gerstenberger, E.S., 1996, Leviticus A Commentary, John Knox Press/Westminister Louisville.

Herzfeld, M., 1980, 'Honour and Shame: Problems in the Comparative Analysis of Moral Systems', MAN 15, 339-340. doi: 10.2307/2801675

Herzfeld, M., 1987, 'As in Your Own House: Hospitality, Ethnography and the Stereotype of Mediterranean Society', in D.D. Gilmore (ed.), Honor and Shame and the Unity of the Mediterranean, pp. 75-89, American Anthropological and the Unity of the Mediter
Association, Washington, DC.

Hayes, J. \& Holladay, C., 1982, Biblical Exegesis: A Beginner's Handbook, John Knox, Atlanta.

Kraemer, R., 1986, 'Hellenistic Jewish Women: The Epigraphical Evidence', Society of Biblical Literature Seminar Papers, 183-200.

Malina, B., 1981, The New Testament world: Insights from cultural anthropology, John Knox, Atlanta.
Malina, B.J., 1993, The New Testament World: Insights from Cultural Anhtropology Westminster/John Knox, Louisville.

Marcus, J., 1999, The Anchor Bible: Mark 1-8 A New Translation with Introduction and Commentary, Doubleday, New York.

Marshall, C.D., 1989, Faith as Theme in Mark's Narrative, CUP, Cambridge.

Meeks, W.A., 1983, The First Urban Christians: The Social World of the Apostle Paul, Yale University Press, New Haven.

Meyers, C., 2000, Women in Scripture: A Dictionary of Named and Unnamed Women in the Hebrew Bible, the Apocryphal/Deutrocanonical Books and the New Testament, William Eerdmans Publishing Company, Michigan.

Milgrom, J., 1990, The Anchor Bible: Leviticus 1-16 A New Translation with Introduction and Commentary, Doubleday, New York.

Myers, C., 1990, Building the Strong Man: A Political Reading of Mark's Story of Jesus, The Edwin Mellen Press, New York.

Neusner, J., 1979, 'Map without territory: Mishnah's system of sacrifices and Sanctury', History of Religions 19, 103-127. doi: 10.1086/462839

Neyrey, J.H., 1991, 'The symbolic world of Luke-Acts: "They turn the world upside Down"', in J.H. Neyrey (ed.), The Social world of Luke-Acts: Models for Interpretation, pp. 271-304, Peabody, Massachusetts.

Peterson, N.R., 1985, Rediscovering Paul: Philemon and the sociology of Paul's narrative world, Fortress Press, Philadelphia.

Seldvigde, M., 1984, 'Mark 5:25-34 and Leviticus 15:19-20: A Reaction to Restrictive Purity Regulations', Journal of Biblical Literature 103(4), 619-623. doi: $10.2307 / 3260473$

Van Aarde, A.G., 2007, 'Inleiding tot die Sosiaal-wetenskaplike kritiese eksegese van Nuwe Testamentiese tekste: Die metodologiese aanloop in die navorsingsgeskiedenis', HTS Teologiese Studies/Theological Studies 63(1), 49-79.

Van Bruggen, J., 1988, Commentaar op het Nieuwe Testament Afdeling Evangeliën: Marcus, Uitgeversmaatschappij J.H. Kok, Kampen.

Van Eck, E., 1995. Galilee and Jerusalem in Mark's story of Jesus: A narratological and social scientific reading, Promedia Printers, Pretoria.

Van Staden, P., 1991, Compassion - the essence of life: A social-scientific study of the religious symbolic universe reflected in the ideology/theology of Luke, the religious symbolic universe reflected in the ideology/theology of Luke,
HTS Teologiese Studies/Theological Studies, suppl. 4, Tydskrifafdeling van die NTS Teologiese Studies/Theological Studien

Wikan, U., 1984, 'Shame and Honour: A Contestable Pair', MAN 19, 635-652. doi: $10.2307 / 2802330$ 